\title{
The impact of the Sanctions and Counter Sanctions on the Russian and EU Member States Economies
}

\author{
Livia Cebotari $^{1}$
}

\begin{abstract}
This paper analyzes the consequences of the diplomatic conflict that began in 2014 between the European Union and the Russian Federation caused by the political and military crisis in Ukraine. In March 2014, the leaders of the European Union condemned the actions of Russia in Ukraine and imposed the first restrictive measures against Russian Federation. In turn, Russia took retaliatory measures materialised in an import ban on certain agricultural food products from the EU. The aim of this research is to identify and evaluate the impact of the sanctions and countersanctions on the economy of the Russian Federation and on bilateral trade between Russia and EU member states. This article will focus on the following main objectives: analyzing the evolution of trade relations between the two major powers in the period 2014-2019, determining the factors that may explain the decline in bilateral trade during the period mentioned above and the factors that may explain why some EU Member States have suffered higher losses than others. In order to achieve the proposed objectives, both qualitative and quantitative analyses were used. Official documents, academic articles and studies conducted by various prestigious think-tanks were analysed. Also, the research is based on consistent trade data between the European Union and the Russian Federation.
\end{abstract}

Keywords: European Union, Russian Federation, economic relations, economic sanctions

JEL Classification: F10, F50, F51

DOI: $10.24818 / \mathrm{REJ} / 2021 / 82 / 05$

\section{Introduction}

This paper analyzes the consequences of the diplomatic conflict that began in 2014 between the European Union and the Russian Federation generated by the political and military crisis in Ukraine. The Euromaidan revolution in the winter of 2013-2014, the referendum in Crimea and its annexation by the Russian

$1 \mathrm{PhD}$ candidate, Bucharest University of Economic Studies, Bucharest, Romania; cebotari.livia.2014@gmail.com

Year XXIV no. 82

December 2021 
Federation, the military conflicts in the self-proclaimed Donetsk and Luhansk People's Republics were the main causes that cooled EU-Russia relations. As the actions of the Russian Federation in Ukraine were considered by the European Union contrary to its objectives and values, the EU introduced sanctions against Russia. The restrictive measures adopted are an instrument of the European Union's Common Foreign and Security Policy (CFSP) and are intended to bring about a change in the Russian government's behavior towards the common neighborhood. Thus, since March 2014, the EU has progressively imposed restrictive measures against Russia, and the Russian Federation has adopted counter-sanctions.

The EU has imposed diplomatic measures, individual restrictive measures (asset freeze and travel restrictions), restrictions on economic relations with Crimea and Sevastopol, economic sanctions and restrictions on economic cooperation. The economic sanctions adopted by the European Union targeted trade in certain sectors. They limited the access of certain Russian banks and companies to the primary and secondary capital markets in the EU. Restrictive measures also prohibit the import, export and direct or indirect transfer of all defense-related materials as well as dual-use items that can be used for military purposes. The sanctions restricted Russia's access to certain sensitive technologies that can be used in the energy sector, for example in oil production and exploration.

The EU has also imposed restrictions on economic relations with Crimea and Sevastopol. These measures include a ban on the import of goods from the peninsula, a ban on the export of certain goods and technology, restrictions on investments and a ban on the provision of tourist services. Economic cooperation measures have suspended funding from the European Investment Bank and the European Bank for Reconstruction and Development for new projects in the Russian Federation. (European Council. EU restrictive measures in response to the crisis in Ukraine).

In turn, Russia took retaliatory measures consisting in an import ban on agricultural and processed food exports from the EU, such as: meat and meat products, certain kinds of fish and related products, milk and dairy products, certain fruit and vegetables.

All restrictive measures, applied by both the European Union and the countersanctions adopted by the Russian Federation, are constantly reviewed and are subject to regular renewals.

Year XXIV no. 82

December 2021 


\section{Problem Statement}

After the EU gradually imposed restrictive measures against Russia in response to the crisis in Ukraine, and the Russian Federation adopted counter-sanctions, researchers and experts in international relations have analyzed the subject. Representatives of the scientific community from different countries evaluated and appraised the effects of the sanctions imposed by the EU against Russia and the counter-sanctions adopted by the Russian Federation.

The main problem in determining the consequences of the restrictive measures adopted by both parties is that their onset coincided with the fall in oil prices. Therefore, the decline observed in the volume of trade between the EU and Russia in the period 2014-2018 was influenced by several economic factors. Using cointegrated vector autoregression models (VAR models) Dreger et al. (2016) established that the depreciation of the ruble was influenced by the decline of oil prices, the sanctions not having a significant impact on this depreciation. Gros and Mustilli (2016) shared the same opinion, arguing that the main factor that caused the disruption of bilateral trade was not the sanctions, but the review that the Russian economy faced. The next year, Gros and Di Salvo (2017) endorsed this idea. The authors reasoned the conclusion by claiming that although the adoption of restrictive measures, the volume of exports from the European Union decreased, they did not lose their position on the Russian market. Ahn and Ludema (2017) stated that sanctions had a smaller macroeconomic impact on the Russian Federation's economy than oil price volatility. Kutlina-Dimitrova (2017) analyzed the effects of the Russian embargo on trade between the EU and the Russian Federation and found that this restrictive measure did not have a major influence on total extra EU exports. However, some categories of products such as fruit and vegetables, dairy products and some types of meat were more severely affected than others. Dolidze (2015) stated that economic sanctions had a boomerang effect, so the restrictive measures adopted by the European Union combined with Russia's embargo on food imported from EU countries created a situation in which all economic actors involved, including EU, suffered losses. Giumelli (2017) analyzed the effects of the restrictive measures imposed in relation to each country, not to the entire union. The author noted that after the adoption of economic sanctions, all EU countries saw a reduction in exports to Russia, but not all 28 countries felt the negative effects of these restrictive measures equally. The same idea was shared by several authors. Ahn and Ludema (2017) argued that sanctions have a different influence on the economy of EU Member States. Oxenstierna (2018) pointed out that the EU acts uniformly when imposing restrictive measures, but the consequences of these sanctions and counter-sanctions vary significantly from one Member State to another. Bali

Year XXIV no. 82

December 2021 
(2018) highlighted the distributive impact of sanctions, emphasizing that some EU Member States were more affected than others. Havlik (2019) argued that the economic effects on individual EU countries vary according to their exposure to the Russian market.

\section{Research Questions/Aims of the research}

The aim of this research is to identify and evaluate the impact of sanctions and counter-sanctions on the economy of Russia, the economies of EU Member States and on bilateral trade between Russia and EU member states in the period 20142019. Based on the conclusions of the authors presented above, this article tries to determine the factors that can explain the decline in bilateral trade during the period mentioned above and the factors that may explain why some EU Member States have suffered higher losses than others. The practical purpose of the paper consists in determining the factors that may clarify why the restrictive measures had a different impact on the EU member states.

\section{Research Methods}

The research methodology combines the specific tool of quantitative analysis with that of qualitative analysis. In order to achieve the proposed objectives, the information collected from official documents (reports of the European Commission and the European Parliament), academic articles and studies conducted by various prestigious think-tanks (The Vienna Institute for International Economic Studies (Wiiw), Centre for European Policy Research (CEPS), Centrum Balticum Foundation) were analysed. At the same time, the research is based on consistent data published by the EU Statistical Office Eurostat. In order to outline a more complete image of the researched subject, it was necessary to collect statistical data, accessing the World Bank database, but also using the commercial software provided by the World Bank - World Integrated Trade Solution (WITS). As a result of accessing Eurostat databases, statistical data on trade in goods between UE member states and the Russian Federation for the period 2010-2019 (quantity, value of imported and exported goods) were collected and processed. The analysis of the structure of imports and exports of goods was also performed, using the Standard Classification for International Trade (SITC). The main sectors of this classification system are: food and live animals; beverages and tobacco; crude materials, inedible (except fuels); mineral fuels, lubricants and related materials; animal and vegetable oils, fats, waxes; chemicals and related products; manufactured goods classified chiefly by material; machinery and transport equipment; miscellaneous manufactured articles; commodities and transactions not classified elsewhere. The quantitative

Year XXIV no. 82

December 2021 
analysis is mainly based on statistical data provided by Eurostat, so the data made available to users by other specialized organizations and institutions may differ considerably from those used in this research. At the same time, these differences could lead to distinct conclusions.

\section{Findings}

\subsection{Effects on Russia}

The impact of sanctions on the economy of the Russian Federation is difficult to assess for several reasons. The Russian economy is extremely vulnerable to fluctuations in oil and gas prices. An indication that the Russian economy is strongly influenced by the oil price is the fact that the budget revenues for the next year are calculated taking into account the forecast oil price for that period. Also, it is quite difficult to disentangle the consequences of sanctions from the effect of structural deficiencies and economic policies in Russia. At the same time, it is impossible to determine how many trade agreements and new contracts have not been signed as a result of EU sanctions.

After fluctuating around an average of 110 U.S. dollars per barrel in 2011-2013, the price of oil has dropped significantly since the second half of 2014. In 2016, the price reached an extremely low level, a barrel of oil being quoted on the international market below 50 US dollars. The fall in oil prices was mainly caused by a supply shock. The increase in oil supply around the world was driven by the unexpected increase in oil production in the US as a result of hydraulic fracturing operations. At the same time, Saudi Arabia continued to export large quantities of oil. Also, at the end of August 2014, oil deliveries from Libya were resumed, after a one-year break. An important factor in reducing the price of oil worldwide was the incapacity of members of the Organization of the Petroleum Exporting Countries (OPEC) to agree on reducing production. Only at the end of 2016, OPEC member countries and other non-member producing states agreed to reduce their production, which allowed the price of oil to return above the threshold of 50 US dollars per barrel. This drop in prices has hit the Russian economy hard, as Russia's main revenues come from oil and gas exports. A problem of the economy of the Russian Federation is the so-called "Dutch disease". This phenomenon is manifested by the over-development of the hydrocarbon extraction industry to the detriment of investments in other economic activities. That is why Russia's economy is very vulnerable to oil price fluctuations. The collapse of the ruble in the second half of 2014 triggered a financial crisis in Russia, which affected the Russian economy, consumers and companies. The losses were in the form of inflation, higher taxes, decreased public 
spending and difficult access to bank credits. In 2016, Russia's GDP was about 1.27 trillion US dollars, the lowest value in 2013-2019 (see Figure 1).

Figure 1. Gross Domestic Product (GDP) of Russia, \$ trillion

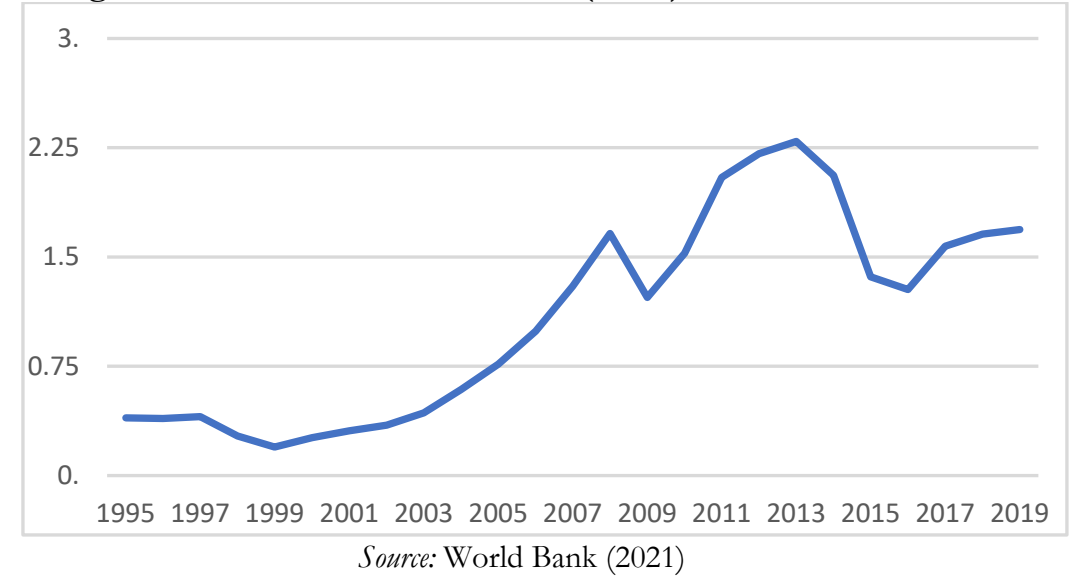

\subsection{Effects on bilateral trade}

The results obtained from the processing of statistical data on the evolution of trade between the EU and Russia showed a decrease in the volume of bilateral trade in the period 2014-2018, compared to the period 2010-2014. The decline in the volume of trade between the EU and Russia in 2014-2016 was determined by the financial crisis in Russia and the counter-sanctions adopted by the Russian Federation.

According to Eurostat, in 2013, 6.88\% of the extra EU exports went to Russia, so the Russian Federation ranked fourth in the EU's top trading partners for exports. During the same period, Russia was the EU's second largest trading partner for imports with a share of $12.27 \%$, being surpassed only by China $(16.59 \%)$ and ahead of the USA (11.82\%). In the period 2014-2020, the position of the Russian Federation among the European Union's trading partners remained relatively constant. In 2019, Russia ranked fourth among the EU's trading partners for exports, with a share of $4.46 \%$, surpassed only by the United States $(22.08 \%)$, China $(11.07 \%)$ and Switzerland $(7.87 \%)$. For imports, it ranked third with a percentage of $7.67 \%$, after China $(20.47 \%)$ and the USA $(14.43 \%)$, but ahead of Switzerland (6.42\%) and Norway (3.5\%). Also, in 2013, the EU was the source of $42.54 \%$ of Russian imports, while the figures for 2018 and 2019 are $37.08 \%$ and $35.8 \%$, respectively. The share of EU imports in the total imports of the Russian Federation has not changed significantly, which shows that the volume of bilateral 
trade has decreased mainly due to other factors, in this case economic sanctions having a secondary role.

During 2010 - 2019, the EU was systematically registering a significant trade deficit in relation to Russia (see Figure 2.). In the same above mentioned period, trade reached its lowest level in 2016, but since 2017 it has begun to gradually recover.

Figure 2. EU-Russia trade in goods, $€$ billion

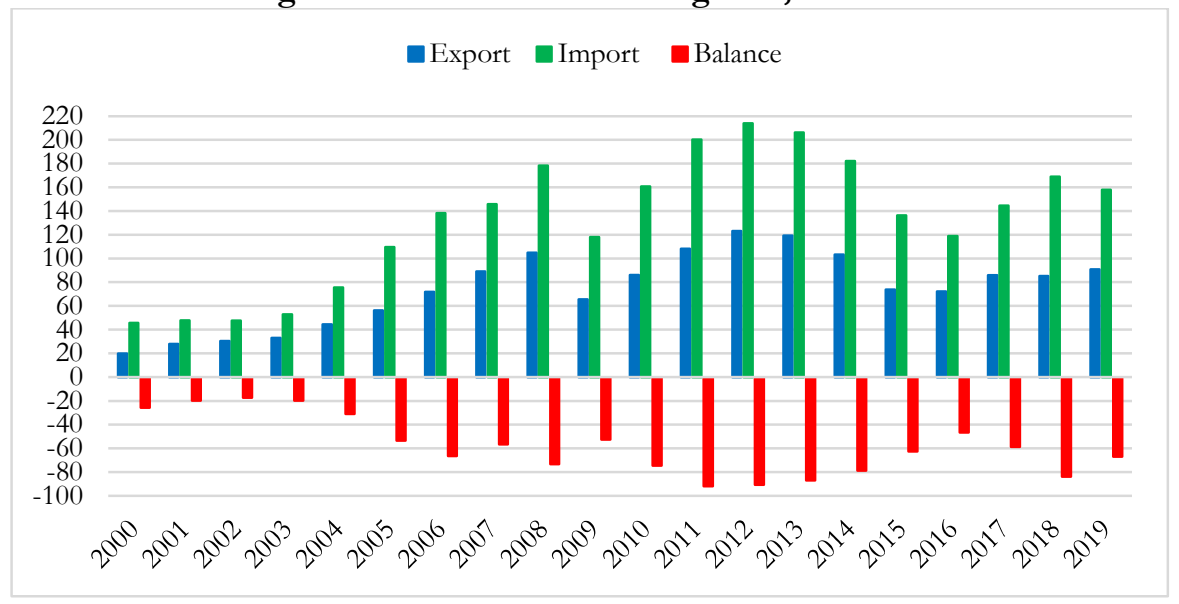

Source: Author's projection using Eurostat database (2021)

Figure 3. EU exports to Russia, $€$ billion

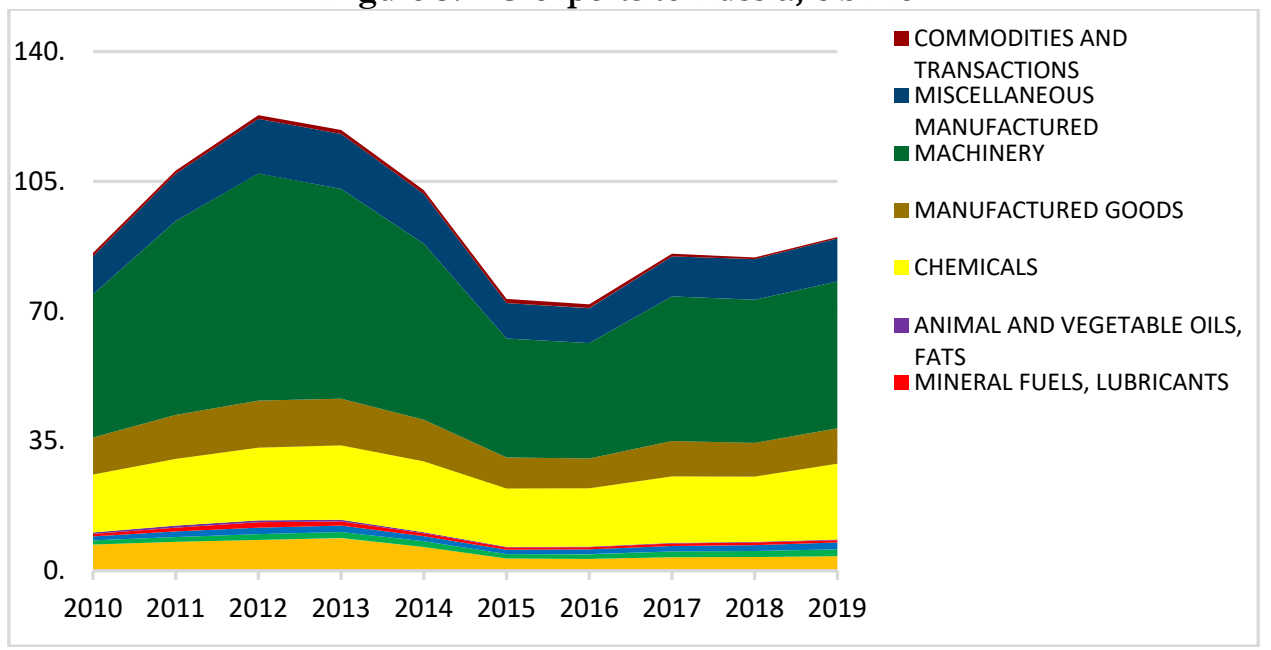

Source: Author's projection using Eurostat database (2021)

Year XXIV no. 82 
In 2019, the structure of European Union exports to the Russian Federation showed that five product groups concentrate $94.59 \%$ of deliveries, respectively: machinery and transport equipment (44\%), chemicals and related products $(22.76 \%)$, miscellaneous manufactured articles $(12.84 \%)$, manufactured goods classified chiefly by material $(10.65 \%)$ and food and live animals $(4.34 \%)$ (see Figure 3.). In the same year, the structure of EU imports from the Russian Federation showed that five product groups represent $96.49 \%$ of total purchases: mineral fuels, lubricants and related materials (72.68\%), manufactured goods classified chiefly by material $(11,78 \%)$, commodities and transactions not classified elsewhere $(4.73 \%)$, chemicals and related products $(3.99 \%)$ and crude materials, inedible (except fuels) $(3.29 \%$ ) (see Figure 4.). Analyzing the statistical data, it can be stated with certainty that the exchange of goods between the European Union and the Russian Federation has an asymmetric character. The structure of imports is highly concentrated, with a single group (mineral fuels, lubricants and related materials) representing $72.68 \%$ of the total, while the structure of exports to Russia is much more diversified. Even if in the period 2014-2019, compared to 2013, the volume of bilateral trade registered a decrease, its structure didn't change. Both the structure of imports and that of exports remained constant with insignificant variations at the level of the same groups of goods. The most important goods exported from the EU to Russia were and remain finished products such as: machinery and equipment, chemicals and medicines and other manufactured products, while imports are concentrated on raw materials, especially energy resources: natural gas, oil, fuels and coal.

Figure 4. EU imports to Russia, billion $€$

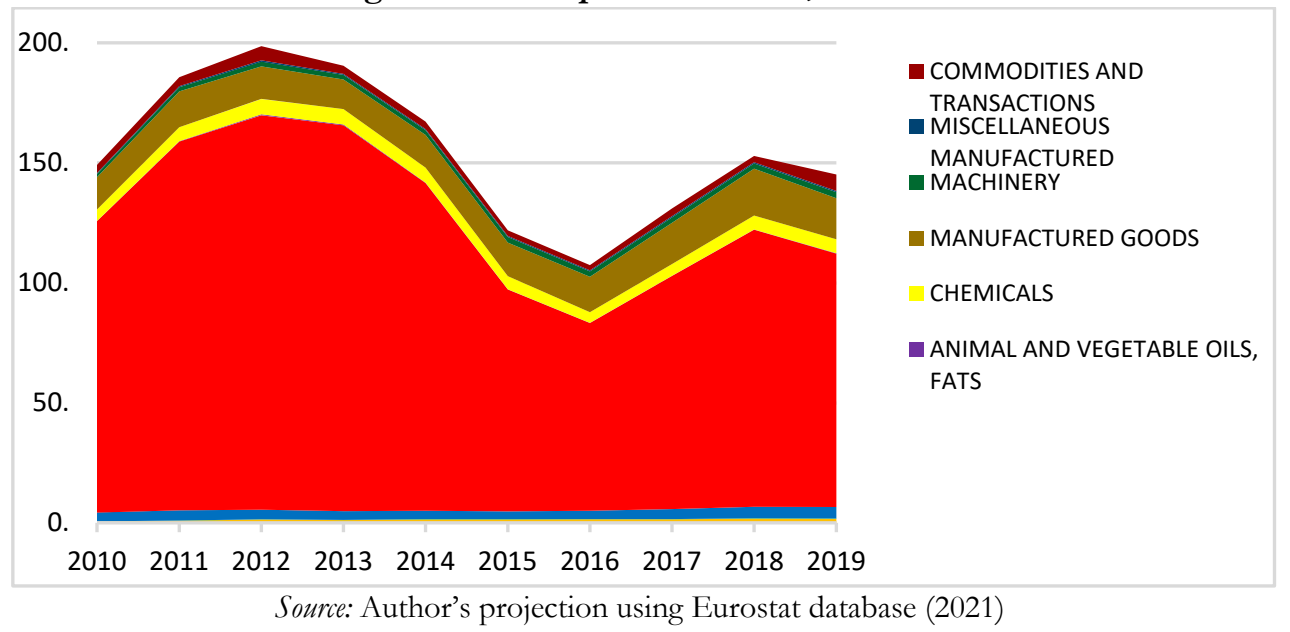

Year XXIV no. 82

December 2021 
Analyzing the trade between every country in the European Union and Russia, a negative balance was frequently identified. Only three countries, Ireland, Luxembourg and Slovenia, had a positive balance throughout the period under review.

At the top of the list of importers in 2019 were Germany, the Netherlands and Italy. Their cumulative imports represent 64 billion euros or $40,5 \%$ of the total imports of EU countries from Russia. In the same year, Germany, followed by Italy and Poland were the states with the largest exports to Russia in 2019, with deliveries of about 42 billion euros, covering about $46,3 \%$ of EU countries' exports to the Russian Federation. At the same time, these three countries were the main exporters of machinery and transport equipment, but also food and live animals to the Russian Federation. Germany, the Netherlands and Poland were the main exporters of chemicals and related products, while Latvia, Lithuania and Italy were at the top of the list of exporters of beverages and tobacco.

Analyzing the statistics, it can be seen that in addition to EU exports of goods that have been directly affected by sanctions and counter-sanctions, exports of other categories of goods have also decreased. The factors that determined this decrease are the financial sanctions and the diminished demand caused by the economic decline of Russia.

The largest decrease in the volume of bilateral trade was recorded in 2016. The fact that this decrease did not occur in 2015, immediately after the imposition of restrictive measures, but in 2016, the year in which the price of oil reached an extremely low level, shows that sanctions are not the main factor influencing bilateral trade in 2014-2018.

\subsection{Factors explaining the differences between the countries}

Some countries, such as Poland, Finland and the Baltic countries, have suffered the most because their geographical location near the Russian Federation has led to more intense bilateral trade. At the same time, the structure of exports and imports was an important factor that determined the existence of these differences between countries. States in which the structure of exports, goods directly affected by sanctions and counter-sanctions, such as agricultural food products and dualuse technology, had a higher share, suffered higher losses. Transport machinery and equipment are the most important category of goods exported by EU Member States to Russia, and countries with a high share of machinery in the structure of exports have fallen sharply. Countries that had a high share of food in their exports also suffered significantly due to the embargo imposed by the Russian Federation on agricultural products from the EU. Countries in which the structure of exports of chemicals, beverages and raw materials had higher shares

Year XXIV no. 82

December 2021 
suffered lower losses, as these categories of goods were not directly affected either by the economic sanctions adopted by the EU or by the food import ban imposed by Russia.

\section{Conclusions}

The fall in world oil prices and the imposition of restrictive measures by the EU against the Russian Federation have led to a depreciation of the Russian ruble. Analysis of statistics showed that the main factor that caused the financial crisis in Russia in 2014-2016 was the fall in oil prices, while restrictive measures played a secondary role. The research demonstrates that after the adoption of restrictive measures all EU countries saw a reduction in exports to Russia, but some member states suffered higher losses. The analysis of the statistical data contributed to identify several factors that can explain why the restrictive measures had a different impact on trade in goods between the Russian Federation and EU member states. These include the geographical proximity, the structure of each country's exports and the way in which the national authorities have interpreted and applied the restrictive measures. It was also found that Russia's main trading partners among the member states suffered the largest losses in nominal terms.

\section{References}

Ahn, D., \& Ludema, R. (2017). Measuring Smartness: Understanding the Economic Impact of Targeted Sanctions. U.S. Department of State, Office of the Chief Economist. Working Paper.

Bali, M. (2018). The Impact of Economic Sanctions on Russia and its Six Greatest European Trade Partners: a Country SVAR Analysis. Finance \& Business, 14 (2), pp. 45-67.

Dolidze, T. (2015). EU Sanctions Policy towards Russia: The Sanctioner-Sanctionee's Game of Thrones. CEPS Working Document No. 402. Retrieved from: https://www.ceps.eu/ceps-publications/eu-sanctions-policy-towardsrussia-sanctioner-sanctionees-game-thrones/.

Dreger, C., Fidrmuc, J., Kholodilin, K., \& Ulbricht, D. (2016) Between the hammer and the anvil: The impact of economic sanctions and oil prices on Russia's ruble. Journal of Comparative Economics, 44(2), pp. 295-308.

European Council. EU restrictive measures in response to the crisis in Ukraine. Retrieved from https:// https://www.consilium.europa.eu/en/policies/sanctions/ ukraine-crisis/. 
Giumelli, F. (2017). The Redistributive Impact of Restrictive Measures on EU Members: Winners and Losers from Imposing Sanctions on Russia. Journal of Common Market Studies, vol. 55 no. 5, pp. 1062-1080.

Gros, D. \& Mustilli, F. (2016). The Effects of Sanctions and Counter-Sanctions on EURussian Trade Flows. CEPS Commentary. Policy Paper. Retrieved from: https://www.ceps.eu/ceps-publications/effects-sanctions-and-countersanctions-eu-russian-trade-flows/.

Gros, D., \& Di Salvo, M. (2017). Revisting Sanctions on Russia and Counter-Sanctions on the EU: the economic impact three years later. CEPS Commentary. Retrieved from: https://www.ceps.eu/ceps-publications/revisiting-sanctions-russiaand-counter-sanctions-eu-economic-impact-three-years-later/.

Havlik, P. (2014). Economic Consequences of the Ukraine Conflict. Vienna: WIIW. Policy Notes and Reports No 14. Retrieved from: https://wiiw.ac.at/economic-consequences-of-the-ukraine-conflict-dlp3427.pdf.

Havlik, P. (2019). EU-Russia sanctions exchange has had important economic and political consequences. Retrieved from: https://wiiw.ac.at/eu-russia-sanctionsexchange-has-had-important-economic-and-political-consequences-n365.html.

Kutlina-Dimitrova, Z. (2017). The economic impact of the Russian import ban: a CGE analysis. International Economics and Economic Policy, 14(4), pp. 538-552.

Oxenstierna, S. (2015). The sanctions against Russia. Are there winners and losers around the Baltic Sea? Some recommendations for the policy-makers. BSR Policy Briefing 9/2018, Centrum Balticum Foundation. Retrieved from: http://www.centrumbalticum.org/files/4090/BSR_Policy_Briefing_10_2 018. 